\title{
A Re-examination of Otoconia from the Shaker Mouse
}

\author{
Roland C. Rouse ${ }^{1}$ and Lars-Göran Johnsson ${ }^{2}$ \\ ${ }^{1}$ Department of Geological Sciences, University of Michigan, Ann Arbor, MI 48109, USA \\ ${ }^{2}$ Department of Otorhinolaryngology, Helsinki University Central Hospital, Helsinki, Finland
}

\begin{abstract}
Summary. We have studied saccular and utricular otoconia from Shaker-1 and Shaker- 2 mice by X-ray diffraction and scanning electron microscopy. In contrast to previous reports, we found that the crystals were composed of calcite rather than polycrystalline hydroxylapatite. These crystals were indistinguishable mineralogically and morphologically from normal mouse otoconia. The reported occurrence of hydroxylapatite otoconia in the Shaker mouse is probably false.
\end{abstract}

Key words: Shaker mouse - Otoconia - Calcite - Hydroxylapatite

\section{Introduction}

In recent years there has been some controversy in the otological literature concerning the identity of the inorganic component of otoconial crystals from the Shaker mouse. Using scanning electron microscopy (SEM) and energy dispersive $\mathrm{X}$-ray analysis (EDA), Chou et al. [8] have described what they consider to be major compositional and morphological abnormalities in some Shaker mouse otoconia. In particular, the presence of "multicrystalline hydroxyapatite" was reported rather than the normal mineral calcite. Their conclusions have more recently been questioned by Anniko and Wróblewski [1], who investigated the quantitative chemical compositions of Shaker and normal mouse otoconia by EDA and were able to find only minor differences between them. They then indicated that the crystals in question were probably ordinary calcite.

We have re-examined the question of abnormalities in Shaker mouse otoconia, and have focused on the crystallography of these structures. Our results support the findings of Anniko and Wróblewski [1], and lead us to believe that several of the conclusions put forth by Chou et al. [8] are in serious error. Indeed, we believe that their report is not even supported by their own experimental evidence. Moreover, certain of their statements concerning the crystal chemistry of biogenic calcium phosphates require correction, as they are not in accord with the known scientific evidence. 


\section{Materials and Methods}

Mice of both the Shaker-1 and Shaker-2 strains, obtained from the Jackson Laboratory (Bar Harbor, Maine, USA), were allowed to grow until 8-9 months of age. They were then sacrificed by decapitation. Auditory bullae were stained overnight in osmium tetroxide buffered with sodium cadodylate, and a total of 10 saccular (4 Shaker-1 plus 6 Shaker-2) and 14 utricular ( 6 Shaker-1 plus 8 Shaker-2) otoconial membranes were obtained by microdissection. The membranes from two mice were mounted on graphite stubs, coated with carbon, and examined in a JEOL JSM-U3 scanning electron microscope operated at $15 \mathrm{kV}$. Qualitative chemical analyses were performed at $20 \mathrm{kV}$ using a solid-state detector coupled to a Tracor Northern Scientific multichannel analyzer. The mineral compositions of all specimens were determined by powder X-ray diffraction, using a $114.6 \mathrm{~mm}$ diameter Debye-Scherrer camera, $\mathrm{CuK} \alpha$ radiation, and 18- to 48 -h exposure times. The longer times were used for specimens having smaller volumes. In addition, the crystallographic unit cell parameters for the crystals from a Shaker- 1 saccule and utricle and a Shaker- 2 saccule and utricle were determined from the X-ray data, using the method of least-squares refinement as well as pure silicon $(a=$ 5.43088 A) from the United States National Bureau of Standards as an internal standard.

\section{Results}

Morphologically, the crystals in our specimens had the appearance of normal mouse otoconia. Some of these were of the disorganized, multifaceted type although this finding is not uncommon in normal animals [17]. All of our specimens gave $\mathrm{X}$-ray patterns consisting of the usual diffraction lines of calcite $\left(\mathrm{CaCO}_{3}\right)$, which is the only crystalline component of normal mammalian otoconia. In addition, some patterns showed two very weak lines at 2.41 and $2.58 \AA$ due to an unidentified trace constituent or contaminant. The qualitative EDA spectra showed major calcium plus traces of magnesium, phosphorus, and sulfur, all of which are normal for mouse otoconia [1]. The latter two elements can reasonably be ascribed to the organic matrix of the crystals, leaving $\mathrm{Mg}^{2+}$ as the only detectible ion substituting for $\mathrm{Ca}^{2+}$ in the crystal structure of the otoconial calcite. The inorganic component of the otoconia is therefore of rather high chemical purity.

A quantitative composition for Shaker mouse otoconia can be derived from their crystallographic unit cell parameters (Table 1) and the qualitative data presented above. The former average to $a=4.981$ and $c=17.015 \AA$ compared to $a=4.9900$ and $c=17.002 \AA$ for pure synthetic calcite at $27^{\circ} \mathrm{C}$ [6]. Since the

\begin{tabular}{lll}
\hline & Saccule & Utricle \\
\hline Shaker-1 & $a=4.981(1)$ & $a=4.980(2)$ \\
& $c=17.033(6)$ & $c=16.988(9)$ \\
Shaker-2 & $a=4.980(2)$ & $a=4.981(2)$ \\
& $c=17.015(9)$ & $c=17.023(9)$ \\
Pure calcite & $a=4.9900(2)$ & $c=17.002(2)$ \\
\hline
\end{tabular}

Table 1. Refined crystallographic unit cell parameters of calcite in Shaker mouse otoconia ${ }^{a}$

${ }^{a}$ Values in Ångström units. Numbers in parentheses are the standard deviations $\times 1000(\times 10,000$ for $a$ of pure calcite) 
cell parameters of biogenic calcite are a known function of its magnesium content [2], these values can be used to estimate the amount of magnesium in Shaker mouse otoconia at approximately $3 \mathrm{~mol}^{\circ} \mathrm{MgCO}_{3}$. This corresponds to the formula $\left(\mathrm{Ca}_{0.97} \mathrm{Mg}_{0.03}\right) \mathrm{CO}_{3}$. Many other divalent cations (e.g., $\mathrm{Fe}^{2+}, \mathrm{Mn}^{2+}$, and $\mathrm{Ni}^{2+}$ ) commonly substitute for $\mathrm{Ca}^{2+}$ in the calcite structure. However, none of these was detectable in our specimens.

\section{Discussion}

The following statement concerning the nature of Shaker mouse otoconia appears in Chou et al. [8]: "The morphology of the crystals containing phosphate and calcium is consistent with their being multicrystalline hydroxyapatite." (The standard mineralogical name for this compound is hydroxylapatite.) Neither our study nor that of Anniko and Wroblewski [1] revealed any trace of this mineral in the animals studied. In fact, if one compares the SEM micrographs published by Chou et al. [8] for Shaker mouse otoconia (their Figs. 4 and 7) and normal mouse otoconia (their Figs. 3, 5, and 6), there is really nothing in them to distinguish the crystals from the two groups of animals. None of the otoconia shown bears any resemblance to normal or pathological hydroxylapatite deposits in mammalian tissues. In general, crystals of biogenic apatite are tabular in habit and much less than $1 \mu \mathrm{m}$ in size [9]. Such crystallites do, in fact, often form polycrystalline aggregates, but these "spherulites" do not resemble mammalian otoconia when they occur in the inner ear $[12,19]$ or in biological tissues generally [16].

The phosphorus content which Chou et al. [8] found in some of their crystals and which they adduce as evidence for the presence of hydroxylapatite can more reasonably be attributed to the organic matter (or matrix) located within the otoconia, overlying the otoconia, and in the gelatinous part of the otoconial membrane $[11,13,18,20]$. It should also be noted that Chou et al. [8] found high phosphorus concentrations in some of their normal mouse otoconia. Using their assumptions about the mineralogical role of phosphate, one would also have to conclude that these normal crystals are hydroxylapatite.

In summary, there is nothing in the evidence produced by any of the three published investigations of Shaker mouse otoconia to show that the latter are anything but normal calcite. There is no need to invoke the presence of hydroxylapatite to explain their phosphate content. Even if Chou et al. [8] should be correct in inferring the presence of a crystalline calcium phosphate, at least six such compounds are found in mammalian tissues. Some of these compounds closely resemble hydroxylapatite $[9,21]$. It is not clear to us how Chou and his coworkers chose among the several possibilities.

In addition to the report of hydroxylapatite in Chou's paper, certain of their other statements concerning the crystal chemistry of biogenic calcium phosphates require comment. On page 240 , it is asserted that "Very careful studies have shown that it is not possible to have carbonate apatite crystals or mixed crystals of carbonate and apatite." The first part of this statement is contradicted by a large body of scientific evidence that has accumulated over the last 
30 years. A perusal of the literature on the subject reveals substantial agreement that $\mathrm{CO}_{3}^{2-}$ substitutes for $\mathrm{OH}^{-}$and probably for $\mathrm{PO}_{4}^{3-}$ in the crystal structure of apatite $[3,7,9,15,21]$. The evidence for a $\mathrm{CO}_{3}^{2-} \rightleftharpoons 2 \mathrm{OH}^{-}$substitution in hydroxylapatite $\left(\mathrm{Ca}_{10}\left(\mathrm{PO}_{4}\right)_{6}(\mathrm{OH})_{2}\right)$ is especially cogent. In fact, a fully carbonate-substituted apatite of this type, $\mathrm{Ca}_{10}\left(\mathrm{PO}_{4}\right)_{6} \mathrm{CO}_{3}$, has been synthesized by Elliot et al. [10]. The second part of Chou's statement is meaningless, since there cannot be "mixed crystals" between an ion (carbonate) and a compound (hydroxylapatite) as the term is generally understood.

We must also question the meaning of the phrase "a complex of hydroxylapatite and otoconial phosphate" found on page 242 of Chou's paper. It makes sense only if the word "octacalcium" is substituted for "otoconial". Hydroxylapatite and and octacalcium phosphate $\left(\mathrm{Ca}_{8} \mathrm{H}_{2}\left(\mathrm{PO}_{4}\right)_{6} \cdot 5 \mathrm{H}_{2} \mathrm{O}\right)$ are closely related chemically and crystallographically. It is true that they form interlayered mixtures on a submicroscopic scale [4], but such mixtures are not properly called complexes.

Lastly, it is stated on page 241 of Chou's paper that "... the observed crystalline forms of otoconia are consistent with the substrates in the utricle and saccule being sulfated mucopolysaccharides (Little 1973)." While the gelatinous parts of the saccular and utricular otoconial membranes are undoubtedly composed of these substances, neither Little [14] nor Chou et al. [8] have shown that this determines either the chemical composition or morphology of the otoconia. In fact, certain synthetic and natural (geologically formed) calcites closely mimic mammalian otoconia in form $[5,18]$. It can safely be said that mucopolysaccharide substrates were in no way involved in the formation of these nonbiogenic crystals.

Acknowledgements. We wish to thank Dr. Joseph E. Hawkins, jr. for his critical review of the manuscript and for making available to us the facilities of the Kresge Hearing Research Institute, in which parts of this study were carried out.

\section{References}

1. Anniko M, Wróblewski R (1983) Qualitative and quantitative analysis of otoconia in the normal and in the genetically deaf inner ear. Am J Otol 4:305-311.

2. Bischoff WD, Bishop FC, Mackenzie FT (1983) Biogenically produced magnesian calcite: inhomogeneities in chemical and physical properties; comparison with synthetic phases. Am Mineral 68:1183-1188

3. Blumenthal NC, Betts F, Posner AS (1981) Formation and structure of Ca-deficient hydroxyapatite. Calcif Tissue Int 33:111-117

4. Brown WE, Schroeder LW, Ferris JS (1979) Interlayering of crystalline octacalcium phosphate and hydroxylapatite. J Phys Chem 83:1385-1388

5. Cailleau P, Dragone D, Girou A, Humbert L, Jacquin C, Roques H (1977) Etude expérimentale de la précipitation des carbonates de calcium en presence de l'ion magnésium. Bull Soc Fr Mineral Crist 100:81-88

6. Chessin HR, Hamilton WC, Post B (1965) Position and thermal parameters of oxygen atoms in calcite. Acta Crystallogr 18:689-693

7. Chickerur NS, Tung MS, Brown WE (1980) A mechanism for incorporation of carbonate into apatite. Calcif Tissue Int 32:55-62

8. Chou JTY, Engelbrecht A, Ilberg Ch v, Juraske P, Scherer H (1980) A study of otoconia of normal mice and shaker mice. Arch Otorhinolaryngol 229:231-243 
9. Elliot JC (1973) The problems of the composition and structure of the mineral components of the hard tissues. Clin Orthop 93:313-345

10. Elliot JC, Bonel G, Trombe JC (1980) Space group and lattice constants of $\mathrm{Ca}_{10}\left(\mathrm{PO}_{4}\right)_{6} \mathrm{CO}_{3}$. J Appl Crystallogr 13:618-621

11. Johnsson LG, Hawkins JE Jr (1967) Otolithic membranes of the saccule and utricle in man. Science $157: 1454-1456$

12. Johnsson LG, Rouse RC, Wright CG, Henry PJ, Hawkins JE Jr (1982) Pathology of neuroepithelial suprastructures of the human inner ear. Am J Otolaryngol 3:77-90

13. Lim DJ (1973) Formation and fate of the otoconia. Ann Otol Rhinol Laryngol 82:23-35

14. Little K (1973) Bone behaviour. Academic Press, New York

15. McConnell D (1973) Apatite, its crystal chemistry, mineralogy, utilization and biologic occurences. Springer, Berlin Heidelberg New York

16. Pautard FGE (1981) Calcium phosphate microspheres in biology. Prog Cryst Growth Charact $4: 89-98$

17. Ross MD, Peacor DR (1975) The nature and crystal growth of otoconia in the rat. Ann Otol Rhinol Laryngol $84: 22-36$

18. Ross MD, Peacor DR, Johnsson LG, Allard LF (1976) Observations on normal and degenerating human otoconia. Ann Otol Rhinol Laryngol 85:310-326

19. Rouse RC, Johnsson LG, Wright CG, Hawkins JE Jr (1984) Abnormal otoconia and calcification in the labyrinths of deaf Dalmatian dogs. Acta Otolaryngol (Stockh) 98:61-71

20. Salamat MS, Ross MD, Peacor DR (1980) Otoconial formation in the fetal rat. Ann Otol Rhinol Laryngol 89:229-238

21. Simpson DR (1972) Problems of the composition and structure of the bone minerals. Clin Orthop 86:260-286

22. Young RA (1975) Some aspects of crystal structural modeling in biological apatites. In: Physico-chemie et cristallographie des apatits d'intérêt biologique. Colloques internationaux CRNR, no. 230. Centre National de la Recherche Scientifique, Paris, pp 21-40

Received December 10, 1984 / Accepted January 16, 1985 